$\mathbf{R}_{\text {ESEArch }} \mathbf{P}_{\text {APER }}$

FOOD SCIENCE

RESEARCH JOURNAL e ISSN-2230-9403 - Visit us : www.researchjournal.co.in Volume 9 | Issue 1 | April, 2018 | 42-47 DOI : 10.15740/HAS/FSRJ/9.1/42-47

\title{
Estimation of glycemic index of developed Heartdiabocare functional snack
}

\author{
Rupali Shinde and Asha Arya
}

\begin{abstract}
A functional food might be functional for all members of a population or for particular groups of the population, which might be defined, for example, by age or by genetic constitution. Glycemic index, or GI, measures how a carbohydratecontaining food raises blood glucose. Foods are ranked based on how they compare to a reference food- either glucose or white bread. A food with a high GI raises blood glucose more than a food with a medium or low GI. Hence an attempt was made to develop a functional snack using functional ingredient and to its nutrient content and glycemic index. Results evidenced that moisture, protein and fat content of functional snack were 2.33 per cent, 17.11 per cent an 12.08 per cent, respectively. Dietary fibre content of functional snack was 22.28 per cent. The soluble and insoluble dietary fibre was 3.86 and 18.42 per cent, respectively. The estimated micronutrients were calcium $296.56 \mathrm{mg}$, iron $7.5 \mathrm{mg}$, zinc $1.48 \mathrm{mg}$, copper $0.397 \mathrm{mg}$ and manganese $1.65 \mathrm{mg}$ per $100 \mathrm{~g}$. Invitro protein digestibility of developed functional snack was 82 per cent. The glycemic index value calculated by determining the ratio of area under the glucose response curve for the heartdiabocare snack and the area for the glucose was 26.27 which was categorized as low per the classification of glycemic index. Hence, it can be concluded that though equicarbohydrate portion of heartdibiocare snack was fed to the subjects, the rise in the blood glucose was significantly less which proves that the developed snack being low in GI is suitable for diabetic patients.
\end{abstract}

Key Words : Glycemic index, Functional snack, Heartdiabocare

How to cite this article : Shinde, Rupali and Arya, Asha (2018). Estimation of glycemic index of developed Heartdiabocare functional snack. Food Sci. Res. J., 9(1): 42-47, DOI : 10.15740/HAS/FSRJ/9.1/42-47. 